\title{
Plantlets Regeneration via Somatic Embryogenesis from the Nucellus Tissues of Kinnow Mandarin (Citrus reticulata L.)
}

\author{
Mubashir Hussain ${ }^{*}$, Naveed Iqbal Raja1 ${ }^{1}$, Muhammad Iqbal1, Anam Iftikhar1, \\ Huma Mehreen Sadaf ${ }^{1}$, Sidra Sabir'1, Muhammad Asim Sultan², \\ Muhammad Nasim Ashraf Faz ${ }^{3}$ \\ ${ }^{1}$ Department of Botany, PMAS Arid Agriculture University, Rawalpindi, Pakistan \\ ${ }^{2}$ Department of Botany, University of Sargodha, Sargodha, Pakistan \\ ${ }^{3}$ Department of Botany, Government College University, Faisalabad, Pakistan \\ Email: *mubashirhussain_22@hotmail.com
}

Received 15 March 2016; accepted 17 April 2016; published 20 April 2016

Copyright (C) 2016 by authors and Scientific Research Publishing Inc.

This work is licensed under the Creative Commons Attribution International License (CC BY). http://creativecommons.org/licenses/by/4.0/

\section{(c) (i) Open Access}

\section{Abstract}

Studies were initiated to explore the role of nucellus tissues and growth regulators in plantlets regeneration via somatic embryogenesis of Kinnow mandarin [Citrus reticulata L. (Blanco)]. Nucellus tissues were cultured on MS medium supplemented with different concentrations and combinations of auxins, cytokinins and malt extract for primary callus induction. The best response for primary callus induction $(90 \%)$ was obtained when MS medium was supplemented with 5 $\mathrm{mg} / \mathrm{l} \mathrm{2,4-D}$ and $500 \mathrm{mg} / \mathrm{l}$ malt extract. Best results for embryogenic callus induction $(80 \%)$ were obtained in $\mathrm{C}_{8}$ medium. The induction of somatic embryos was highest when MS medium was supplemented with $1 \mathrm{mg} / \mathrm{l}$ BAP and maturation of somatic embryos occurred when MS medium was supplemented with $5 \mathrm{mg} / \mathrm{l}$ 2,4-D and $1 \mathrm{mg} / \mathrm{l}$ BAP. Maximum plantlets were regenerated (92\%) from the somatic embryos on half strength MS medium with no hormones. The plantlets were successfully acclimatized in different potting mixtures and highest survival rate $(100 \%)$ was achieved in potting mixture containing sand and peat moss $(2: 1)$.

\section{Keywords}

Tissue Culture, MS Media, Citrus, Nucellus Tissue, Callogenesis, Somatic Embryos

\footnotetext{
${ }^{*}$ Corresponding author.
}

How to cite this paper: Hussain, M., Raja, N.I., Iqbal, M., Iftikhar, A., Sadaf, H.M., Sabir, S., Sultan, M.A. and Faz, M.N.A. (2016) Plantlets Regeneration via Somatic Embryogenesis from the Nucellus Tissues of Kinnow Mandarin (Citrus reticulata L.). American Journal of Plant Sciences, 7, 798-805. http://dx.doi.org/10.4236/ajps.2016.76074 


\section{Introduction}

Citrus belongs to family Rutaceae having 150 genera and 15,000 species and it is distributed mostly in tropical and temperate region of the planet [1]. There are 11 genera and 27 species of the family in Pakistan. A number of major genera of family Rutaceae are Citrus, Murraya, Zanthoxylum and Ruta etc. [2]. Citrus origin is supposed to be southern slope of Himalayan region and north eastern area of China and adjacent India [3]. It has high dietary value and is a prosperous source of vitamin $\mathrm{C}$ in combination with macromolecules such as amino acids, organic acids and sugar as well as minerals comparable to magnesium and calcium in sufficient quantity [4].

According to an estimate, Pakistan is the $1^{\text {st }}$ largest producer of Kinnow mandarin. In recent years, Pakistan's average yield of Kinnow is about 9.2 tons per hectare which reflects poor production performance when we compared it with developed countries. This low yield is due to attacks of different types of pathogens that are viruses, bacteria and fungi etc.

The role of tissue culture in genetic engineering and biotechnology was first time exemplified by Kanta and Maheshwari in 1962. Gene transfer, selection and regeneration of transformants are nowadays employed by the plant tissue culture techniques [5]. According to Helal [6], tissue culture can be employed as substitute to conservative methods in vitro propagation with the purpose of increasing the developmental rate of preferred genotypes and commercial micropropagation.

In Citrus, few studies have been carried out on somatic embryos formation from nucellus tissue derived callus. Somatic embryogenesis is the formation of zygotic embryo like structure from the somatic cells without gametic fusion [7]. Somatic embryogenesis is usually used in large scale production of plants and artificial seeds [8]. Somatic embryogenesis is an efficient method of plant regeneration allowing rapid production of large number of plants within short period. So far there is lit bit information which is available for somatic embryogenesis in Citrus reticulata, which is the most widely grown Citrus crop in Pakistan. In Citrus cultivars, the potential for embryogenic calluses was reported from various explants such as excised nucelli [9], abortive ovules [10], unfertilized ovules [11], undeveloped ovules [12], juice vesicles [13], anthers [14], styles and stigmas [15] as well as from root segments, cotyledons and epicotyls [16].

Successful somatic embryogenesis from nucellus tissues of different Citrus cultivars was achieved by various researchers [17]-[19].

The present investigation was undertaken to develop the in vitro suitable protocol for plantlets regeneration of Kinnow (Citrus reticulata L.) from nucellus tissues through somatic embryogenesis.

\section{Materials and Methods}

The present research work was carried out at Plant Tissue Culture Laboratory, Department of Botany, PMASArid Agriculture University Rawalpindi, Pakistan during the year 2014-15.

\subsection{Source of Plant Material}

Mature trees of Citrus reticulata from the Bhalwal region of district Sargodha were used as the source of plant material.

\subsection{Preparation of Explants}

Immature fruits (10 weeks after anthesis) were cleaned thoroughly with running tap water to remove all the remains of surface contaminants. Then they were surface sterilized in $70 \%$ ethanol for 5 minutes followed by immersion in $20 \%$ Chlorax solution also containing $1 \%$ sodium hypochlorite solution. Finally immature fruits were rinsed three times with autoclaved distilled water. For somatic embryo induction, immature seeds were separated under aseptic condition. Immature seeds were cut by scalpel and nucellus halves were separated. Then the nucellus halves were kept for 24 hours in an antioxidant solution containing $150 \mathrm{mg} / \mathrm{l}$ citric acid and $100 \mathrm{mg} / \mathrm{l}$ ascorbic acid. Thereafter, nucellus tissues were rinsed three times in sterile distilled water, then sterilized in $20 \%$ chlorax solution, containing 1\% NaOCl and a drop of tween 20 for 15 minutes. The nucellus tissues were finally rinsed three times in double distilled water and cultured.

\subsection{Media Preparation and Culture Conditions}

All the in vitro work was carried out on MS medium (Murashige and Skoog, 1962). For the preparation of MS 
medium, exact quantities of all the components of particular medium were mixed. $30 \mathrm{~g}$ sucrose was added and final volume of the medium $(1 \mathrm{~L})$ was made by the addition of double distilled water. The $\mathrm{pH}$ of the medium was adjusted between $5.7-5.8$ by adding drops of $1 \mathrm{~N} \mathrm{HCl}$ and $1 \mathrm{~N} \mathrm{NaOH}$. Medium was solidified with $0.8 \%$ agar. The MS medium was heated on hot plate to melt the agar. Finally the medium was autoclaved at 15 psi for 15 minutes at $121^{\circ} \mathrm{C}$. The medium was then poured into petri plates as well as in test tubes in laminar hood. Cultures were then placed in growth chamber at $25^{\circ} \mathrm{C}$ with a photoperiod of 16 hours light. Light intensity was maintained upto 2500 lux.

\subsection{Callus Induction}

For callus induction, Nucellus tissues were cultured on MS medium containing varying concentrations of different combinations of phytohormones and malt extract. Nucellus tissues were cultured in 16 varying concentrations of four different combinations (S1) $=$ MS + 2,4-D + malt extract, (S2) $=$ MS + 2,4-D + BAP, (S3) $=$ MS + BAP + malt extract, $(\mathrm{S} 4)=\mathrm{MS}+\mathrm{BAP}+\mathrm{NAA}$ as shown in Table 1 . The nucellus tissues were inoculated in the testing media in laminar air flow cabinet and wrapped with aluminum foil. The inoculated cultures were then placed in a growth chamber at $25^{\circ} \mathrm{C}$ for four weeks.

\subsection{Primary Callus Induction and Proliferation}

The response for primary callus induction was observed in all the testing combinations and it was found that the percentage for primary callus induction vary in all the testing combinations. The primary calluses were then incubated on half strength MS medium in $\mathrm{C}_{3}$ medium for S1 combination, $\mathrm{C}_{8}$ medium for S2 combination, $\mathrm{C}_{10}$ medium for $\mathrm{S} 3$ combination and $\mathrm{C}_{13}$ medium for $\mathrm{S} 4$ combination for callus proliferation. The process of callus proliferation was continued for almost 12 weeks with sub culturing after every 4 weeks.

\subsection{Embryogenic Callus Induction}

Creamed colored compact calluses were divided and incubated on half strength MS medium $\left(\mathrm{C}_{8}\right.$ and $\left.\mathrm{C}_{10}\right)$ for four weeks. Embryogenic calluses were obtained at the end of this period.

\subsection{Somatic Embryo Induction and Maturation}

The embryogenic calluses which were obtained previously from the nucellus tissues were cultured on MS medium containing BAP at $1 \mathrm{mg} / \mathrm{l}$ and $1.5 \mathrm{mg} / \mathrm{l}$ for somatic embryo induction. This step was continued for four weeks. Embryo maturation occurred on MS medium containing 5 mg/l 2,4-D and 1 mg/l BAP.

\subsection{Separation of Somatic Embryos}

Cultures having somatic embryos were shifted to MS liquid medium in jars inside laminar air flow cabinet and then the jars were placed on orbital shaker for shaking cultures. The cultures were shacked for 6 hours to completely separate the somatic embryos from each other.

\subsection{Plantlets Regeneration}

Isolated somatic embryos were cultured on half strength MS medium with no hormones. The MS medium was also fortified with BAP, BAP+ Kin in three concentrations each to find out the best medium for plantlets regeneration.

\subsection{Acclimatization/Hardening off}

The plantlets which have good root and shoot system were successfully acclimatized in different types of potting mixtures. Plantlets were removed from the culture jars and cleaned with sterile distilled water to remove all the remains of growth medium from the roots. The plantlets were then planted in plastic pots filled with different combinations (Sand, Sand + Peat moss (2:1), sand + soil + Peat moss (1:1:1) and sand+ soil + Compost (1:1:1) hardening mixtures. The plantlets were then covered with plastic sheets for 15 days and then cover was removed gradually. The acclimatization process was continued for almost 12 weeks. 


\subsection{Statistical Analysis}

All the experiments were laid out in completely randomized design arrangements of treatments. All treatments were replicated three times with ten explants per treatments. To detect the significant difference between means, the collected data was subjected to analysis of variance. Statistical analysis was done using STATISTICS 8.1 and Microsoft Excel 2007 software.

\section{Results and Discussions}

It is obvious from Figure 1 that Kinnow mandarin can be in vitro propagated via somatic embryogenesis from the calluses obtained from the nucellus tissues. Table 1 shows that MS medium was supplemented with varying concentrations of four different combinations of phytohormones and malt extract for primary callus induction. Primary calluses were formed in all the tested combinations but percentages vary in different concentrations of each tested combination. As shown in Table 1 when MS medium was supplemented with different concentrations of 2,4-D along with constant concentration of malt extract, the rate of callus induction was increased with the increase in concentration of 2,4-D. The response for primary callus induction was $68 \%$ when supplemented with $2 \mathrm{mg} / \mathrm{l}$ 2,4-D and $500 \mathrm{mg} / \mathrm{l}$ malt extract. Table 1 further depicted that by increasing the concentration of 2,4-D with constant concentration of malt extract, the response for primary callus induction was increased. The effects of auxins on callus induction in citrus cultivars have already been reported by various researchers [20] [21].

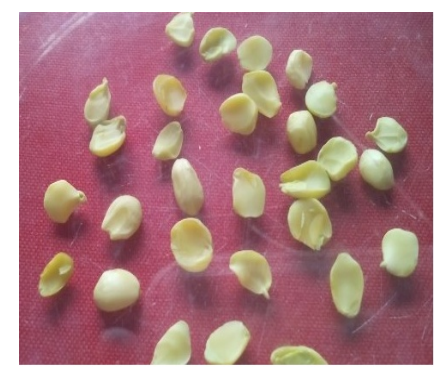

(a)

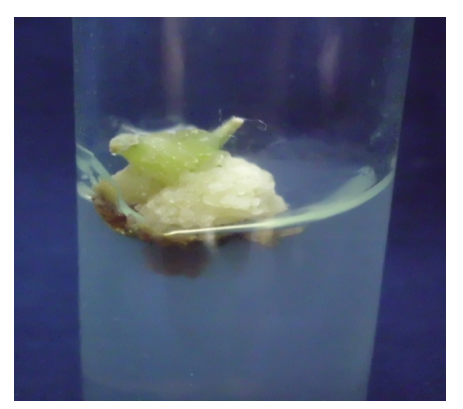

(c)

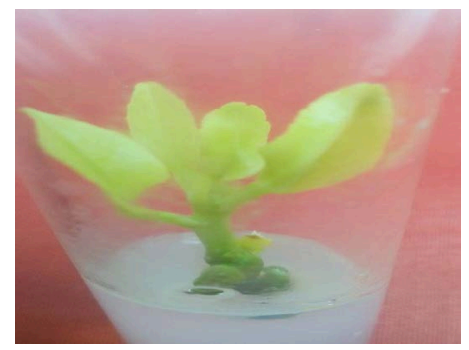

(e)

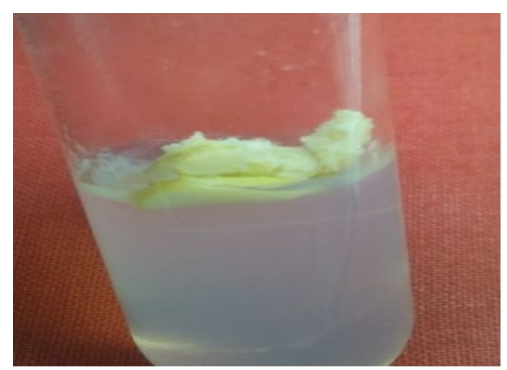

(b)

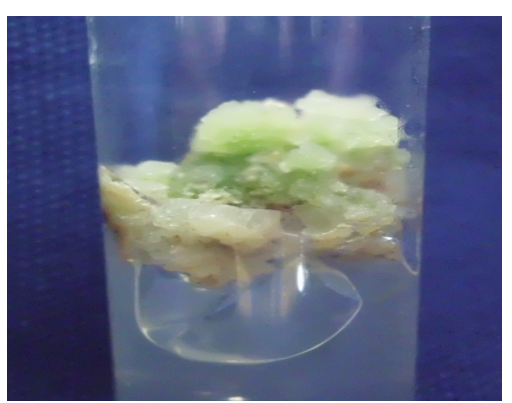

(d)

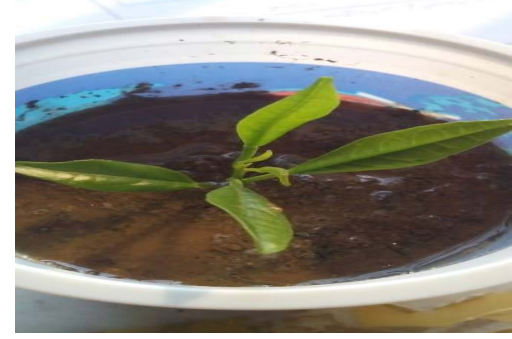

(f)

Figure 1. The time line of plantlet regeneration via somatic embryogenesis in Citrus reticulate cv. Kinnow; (a) Isolated Nucellus tissues; (b) Primary callus; (c) and (d) Embryogenic callus; (e) Germinating embryos into plantlet; (f) Plantlet hardening in pot after acclimatization. 
Table 1. Effect of various medium compositions on primary callus induction percentage and proliferation in Citrus reticulata L.

\begin{tabular}{|c|c|c|c|c|c|}
\hline Treatment & Media & Conc. (mg/l) & $\begin{array}{l}\text { No. of explants } \\
\text { cultured }\end{array}$ & $\begin{array}{c}\text { Primary callus } \\
\text { induction percentage }\end{array}$ & Proliferation \\
\hline $\mathrm{C}_{1}$ & \multirow{4}{*}{ MS + 2,4-D + Malt extract } & $2.0+500$ & 10 & $6.8 \pm 0.264^{\mathrm{bcd}}$ & ++ \\
\hline $\mathrm{C}_{2}$ & & $3.0+500$ & 10 & $7.3 \pm 0.110^{\mathrm{abc}}$ & ++ \\
\hline $\mathrm{C}_{3}$ & & $4.0+500$ & 10 & $8.0 \pm 0.310^{\mathrm{ab}}$ & +++ \\
\hline $\mathrm{C}_{4}$ & & $5.0+500$ & 10 & $9.0 \pm 0.525^{\mathrm{a}}$ & ${ }^{++++}$ \\
\hline $\mathrm{C}_{5}$ & \multirow{4}{*}{$\mathrm{MS}+2,4-\mathrm{D}$ + BAP } & $1.0+5.0$ & 10 & $8.8 \pm 0.984^{\mathrm{a}}$ & ${ }^{++}$ \\
\hline $\mathrm{C}_{6}$ & & $2.0+3.0$ & 10 & $8.0 \pm 0.490^{\mathrm{a}}$ & ++ \\
\hline $\mathrm{C}_{7}$ & & $3.0+2.0$ & 10 & $6.2 \pm 0.070^{\mathrm{b}}$ & ++ \\
\hline $\mathrm{C}_{8}$ & & $5.0+1.0$ & 10 & $8.8 \pm 0.624^{\mathrm{a}}$ & ${ }^{++++}$ \\
\hline $\mathrm{C}_{9}$ & \multirow{4}{*}{ MS + BAP + malt extract } & $1.0+500$ & 10 & $7.2 \pm 0.346^{\mathrm{cd}}$ & + \\
\hline $\mathrm{C}_{10}$ & & $1.5+500$ & 10 & $7.8 \pm 0.721^{\mathrm{de}}$ & ++ \\
\hline $\mathrm{C}_{11}$ & & $2.0+500$ & 10 & $6.9 \pm 0.872^{\text {cd }}$ & ++ \\
\hline $\mathrm{C}_{12}$ & & $2.5+500$ & 10 & $5.8 \pm 0.380^{\mathrm{ef}}$ & + \\
\hline $\mathrm{C}_{13}$ & \multirow{4}{*}{ MS + NAA + BAP } & $0.5+0.5$ & 10 & $4.6 \pm 0.180^{\mathrm{a}}$ & +++ \\
\hline $\mathrm{C}_{14}$ & & $1.0+0.5$ & 10 & $5.8 \pm 0.330^{\mathrm{b}}$ & ++ \\
\hline $\mathrm{C}_{15}$ & & $1.5+0.5$ & 10 & $6.2 \pm 0.485^{\mathrm{b}}$ & ++ \\
\hline $\mathrm{C}_{16}$ & & $2.0+0.5$ & 10 & $8.2 \pm 0.341^{\mathrm{c}}$ & + \\
\hline
\end{tabular}

${ }^{+}$, Poor; ${ }^{++}$, fair; ${ }^{+++}$, good; ${ }^{+++}$, excellent. Mean followed by different letters in the same column differ significantly at $p=0.05$ according to Duncan's new multiple range test.

Table 1 shows that MS medium was also supplemented with various concentrations of BAP along with constant concentration of malt extract. Data presented in Table 1 showed that further increase or decrease in the concentration of BAP beyond $1.5 \mathrm{mg} / \mathrm{l}$ and $500 \mathrm{mg} / \mathrm{l}$ malt extract did not show good results for primary callus induction as compared to this concentration (Figure 1(b)). Malt extract was recognized as a substance for callus initiation with asexual embryogenic potential. Similar results were achieved in "valentia” (sweet orange) Pasqual et al. [22] and "Ponkan" mandarin [23]. Therefore it is necessary to add malt extract in callus induction media as well as for somatic embryo induction. Moreover callus produced in the medium containing malt extract was heavier and embryogenic in nature. These results are in conformity with those of Chen and Zhang [23] in Citrus reticulata and Miah et al. [17] in Citrus macroptera.

2,4-D in combination with BAP was also tested and it was found that $5 \mathrm{mg} / \mathrm{l} 2,4-\mathrm{D}$ and $1 \mathrm{mg} / \mathrm{l} \mathrm{BAP}$ was most effective in callus induction. At this concentration the response for primary callus induction was 88\%. Our findings are in line with Al-Taha et al. [19] who also obtained similar findings in an attempt for primary callus induction in Citrus sinensis. The primary callus induction response was also observed by Ramdan et al. [24] who reported that 2,4-D and BAP was effective in callus induction in five different citrus rootstocks. Among different concentrations of NAA and BAP, the best result for callus induction was obtained at 0.5 mg/l NAA and 0.5 $\mathrm{mg} / \mathrm{l}$ BAP. Our results are in strong agreement with Singh et al. [25] who reported that concentration of NAA at $0.5 \mathrm{mg} / \mathrm{l}$ and $0.5 \mathrm{mg} / \mathrm{l} \mathrm{BAP}$ was most effective in callus initiation in Citrus jambhiri. Our results are in strongly agreement with Haoa et al; Gitarani and Vinash [26] [27] who reported that increasing the level of auxins such as 2,4-D and NAA in MS medium resulted in the increase in callus induction percentage.

Creamed colored compact calluses were obtained and cultured on half strength MS medium in different concentrations of two combinations for embryogenic callus induction. In the tested combinations it was found that 
2,4-D and BAP was more appropriate for embryogenic potential (Table 2, Figure 1(c) \& Figure 1(d)). Our findings regarding to embryogenic callus induction for Citrus reticulata are in strongly agreement with Khan et al. [28] who also reported similar results. Due to presence of auxins, Gloria et al. [29] observed good embryoid formation in citrus cultivars and good response for somatic embryo induction when MT medium was supplemented with $500 \mathrm{mg} / \mathrm{l}$ malt extract. Embryogenic calluses were then cultured in different concentrations of BAP for somatic embryo induction. It is evident from Table 3 that when MS medium was supplemented with different concentrations of BAP for asexual embryo induction, the best response for somatic embryo induction was obtained in MS medium containing $1 \mathrm{mg} / \mathrm{l}$ BAP after 4 weeks. At this concentration $80 \%$ somatic embryos were obtained. Somatic embryos which were obtained having both shoot and root apices that are anatomically and physiologically comparable to zygotic embryos [30]. Tomaz et al. [31] observed the combined effects of NAA in combination with BAP on the embryoids formation percentage in citrus cultivars.

After the separation of somatic embryos, they were transferred to half strength MS medium containing different concentrations of BAP, BAP + Kin and devoid of growth regulators. Findings (Table 4, Figure 1(e)) showed that MS medium which no hormones was more successful in obtaining plantlets from somatic embryos as compared to MS medium supplemented with cytokinins. The medium without PGHs induced $92 \%$ plantlets regeneration. Al-Taha et al. [19] also confirmed our findings. Our results are also in line with Rajdan and Miah et al. [17] [32] who observed successful embryo germination on medium without any phytohormones. The addition of cytokinins also had influence on plantlets regeneration but slightly less significant as compared to hormonal free media. It is evident from Table 4 that $\mathrm{M}_{4}$ (BAP @ $\left.1 \mathrm{mg} / \mathrm{l}\right)$ and $\mathrm{M}_{8}(\mathrm{BAP}+\mathrm{Kin} @ 1.0 \mathrm{mg} / \mathrm{l}+1.5$ $\mathrm{mg} / \mathrm{l})$ medium was most successful in obtaining plantlets from the somatic embryos. Jumin et al. [33] observed $0.1 \mathrm{mg} / \mathrm{l} \mathrm{GA}+0.1 \mathrm{mg} / \mathrm{l}$ zeatin was effective for embryoid to plantlets regeneration. There are some reports that virus free plants can be obtained via somatic embryogenesis [34].

In vitro propagated plantlets of Citrus reticulata removed from the medium and detached the adhering gel. Then they were shifted into plastic pots in four different types of potting mixtures (Table 5). The plantlets were then

Table 2. Effect of various medium compositions on embryogenic callus induction in Citrus reticulata L.

\begin{tabular}{cccccc}
\hline Treatment & Media & Conc. (mg/l) & $\begin{array}{c}\text { No of calli } \\
\text { cultured }\end{array}$ & $\begin{array}{c}\text { Embryogenic } \\
\text { callus induction \%age }\end{array}$ & $\begin{array}{c}\text { Age of culture } \\
\text { (Weeks) }\end{array}$ \\
\hline $\mathrm{C}_{8}$ & MS + 2,4-D + BAP & $5.0+1.0$ & 10 & $8.5 \pm 0.171^{\text {bcd }}$ & 04 \\
$\mathrm{C}_{10}$ & MS + BAP + malt extract & $1.5+500$ & 10 & $7.8 \pm 0.651^{\text {cd }}$ & 04 \\
\hline
\end{tabular}

Mean followed by different letters in the same column differ significantly at $p=0.05$ according to Duncan’s new multiple range test.

Table 3. Effect of various concentrations of BAP on somatic embryo induction in Citrus reticulata L.

\begin{tabular}{ccccc}
\hline Treatment & Media & Conc. (mg/l) & $\begin{array}{c}\text { No of embryogenic } \\
\text { calli cultured }\end{array}$ & $\begin{array}{c}\text { Somatic embryo } \\
\text { induction \%age }\end{array}$ \\
\hline & MS + BAP & 1.0 & 10 & $8.0 \pm 0.382^{\mathrm{fg}}$ \\
(Weeks) & 10 & $6.0 \pm 0.220^{\text {cd }}$ \\
\hline
\end{tabular}

Mean followed by different letters in the same column differ significantly at $p=0.05$ according to Duncan's new multiple range test.

Table 4. Effect of various medium compositions on plantlets regeneration percentage from somatic embryos in Citrus reticulata L.

\begin{tabular}{|c|c|c|c|c|c|}
\hline Treatment & Media & Conc. (mg/l) & $\begin{array}{l}\text { No of somatic } \\
\text { embryo cultured }\end{array}$ & $\begin{array}{c}\text { Plantlets } \\
\text { regeneration }\end{array}$ & $\begin{array}{c}\text { Age of culture } \\
\text { (Weeks) }\end{array}$ \\
\hline $\begin{array}{l}\mathrm{M}_{1} \\
\mathrm{M}_{2} \\
\mathrm{M}_{3} \\
\mathrm{M}_{4}\end{array}$ & MS + BAP & $\begin{array}{c}0.0 \\
0.25 \\
0.5 \\
1.0\end{array}$ & $\begin{array}{l}10 \\
10 \\
10 \\
10\end{array}$ & $\begin{array}{c}9.2 \pm 0.264^{\mathrm{h}} \\
6.2 \pm 0.195^{\mathrm{fgh}} \\
7.5 \pm 0.305^{\mathrm{efg}} \\
8.0 \pm 0.200^{\mathrm{de}}\end{array}$ & $\begin{array}{l}06 \\
06 \\
06 \\
06\end{array}$ \\
\hline $\begin{array}{l}M_{5} \\
M_{6} \\
M_{7} \\
M_{8}\end{array}$ & MS + BAP + Kin & $\begin{array}{l}0.0+0.0 \\
1.0+0.5 \\
1.0+1.0 \\
1.0+1.5\end{array}$ & $\begin{array}{l}10 \\
10 \\
10 \\
10\end{array}$ & $\begin{array}{c}9.2 \pm 0.351^{\mathrm{g}} \\
5.0 \pm 0.180^{\mathrm{efg}} \\
6.8 \pm 0.095^{\mathrm{ab}} \\
8.2 \pm 0.390^{\mathrm{cd}}\end{array}$ & $\begin{array}{l}06 \\
06 \\
06 \\
06\end{array}$ \\
\hline
\end{tabular}

Mean followed by different letters in the same column differ significantly at $p=0.05$ according to Duncan's new multiple range test. 
Table 5. Effect of various potting mixtures on the survival of plantlets of Citrus reticulata L.

\begin{tabular}{cccc}
\hline Sr. No. & Treatments & Frequency of acclimatization of plantlets in pots & Age of plantlets (weeks) \\
\hline 1 & Sand & 80 & 12 \\
2 & Sand + peat moss (2:1) & 100 & 12 \\
3 & Sand + soil + peat moss (1:1:1) & 95 & 12 \\
4 & Sand + soil + compost (1:1:1) & 90 & 12 \\
\hline
\end{tabular}

covered with polypropylene sheets. The polypropylene sheets were slowly removed after a period of almost 2 weeks. The process of hardening off was continued for almost 3 months. The highest survival rate was achieved (100\%) in potting mixture (Figure $1(f)$ ) having sand and peat moss (2:1) followed by the sand, soil and peat moss (1:1:1). The percentage of success during hardening off was $90 \%$ by using sand, soil and compost (1:1:1). The findings of Al-Taha et al. [19] also affirmed our results who reported that plantlets which were obtained and transferred to media containing sand as well as peat moss and highest survival rate (100\%) were achieved. Rana and Singh [35] successfully established in vitro plantlets of Kagzi lime in sand, soil and compost (1:1:1) mixture.

\section{Conclusion}

The results of the present research work standardize the protocols for plantlets regeneration via somatic embryogenesis from the nucellus tissues in Kinnow mandarin. The protocols which have been established can be used in future to transgene and enhance the commercial values of Kinnow mandarin. The techniques established in present study can also be tried for other fruit crops which are difficult to propagate through conventional methods.

\section{References}

[1] Ladaniya, M.S. (2008) Citrus Fruit Biology, Technology and Evaluation. Elsevier Inc..

[2] Perveen, A. and Qaiser, M. (2005) Pollen Flora of Pakistan XLV. Rutaceae. Pakistan Journal of Botany, 37, 495-501.

[3] Gmitter, F.G. and Hu, X. (1990) The Possible Role of Yunnan, China, in the Origin of Contemporary 78 Citrus Species (Rutaceae). Economic Botany, 44, 267-277. http://dx.doi.org/10.1007/BF02860491

[4] Niaz, A.C., Maken, M.N. and Malik, S.A. (2004) Native Home, Historical Background and Importance of Citrus Fruits in Pakistan. Proceedings of the 1st International Conference on Citriculture, University of Agriculture Faisalabad, 2004, 48-56.

[5] Shah, A.H., Rashid, N., Haider, M.S., Saleem, F., Tahir, M. and Iqbal, J. (2009) An Efficient, Short and Cost-Effective Regeneration System for Transformation Studies of Sugarcane (Saccharum officinarum L.). Pakistan Journal of Botany, 41, 609-614.

[6] Helal, N.A.S. (2011) The Green Revolution via Synthetic (Artificial) Seeds: A Review. Research Journal of Agriculture and Biological Sciences, 7, 464-477.

[7] Tabassum, B., Nasir, I.A., Farooq, A.M., Rehman, Z., Latif, Z. and Husnain, T. (2010) Viability Assessment of in Vitro Produced Synthetic Seeds of Cucumber. African Journal of Biotechnology, 9, 7026-7032.

[8] Phillips, G.C. (2004) In Vitro Morphogenesis in Plants-Recent Advances. In Vitro Cellular and Developmental Biology-Plant, 40, 342-345. http://dx.doi.org/10.1079/IVP2004555

[9] Rangan, T.S., Murashige, T. and Bitters, W.P. (1968) In Vitro Initiation of Nucellar Embryos in Monoembryonic Citrus. Horticulture Science, 3, 226-227.

[10] Bitters, W.P., Murashige, T., Rangan, T.S. and Nauer, E. (1970) Investigations on Established Virus-Free Plants through Tissue Culture. Calif. Citrus Nursery Society, 9, 27-30.

[11] Button, J. and Bornman, C.H. (1971) Development of Nucellar Plants from Unpollinated and Unfertilized Ovules of the Washington Navel Orange in Vitro. South African Journal of Botany, 37, 127-134.

[12] Starrantino, A. and Russo, F. (1980) Seedlings from Undeveloped Ovules of Ripe Fruits of Polyembryonic Citrus Cultivars. Horticulture Science, 15, 296-297.

[13] Nito, N. and Iwamasa, M. (1990) In Vitro Plantlets Formation from Juice Vesicle Callus of Satsuma (Citrus unshiu Mare.). Plant Cell Tissue and Organ Culture, 20, 137-140. http://dx.doi.org/10.1007/BF00114712 
[14] Hidaka, T., Yamada, Y. and Shichijo, T. (1981) Plantlet Formation from Anthers of Citrus aurantium L. Proc. Int. Soc. Citricult, 1, 153-155.

[15] Carimi, F., De Pasquale, F. and Crescimanno, F.G. (1995) Somatic Embryogenesis in Citrus from Styles Culture. Plant Science, 105, 81-86. http://dx.doi.org/10.1016/0168-9452(94)04032-C

[16] Gill, M.I.S., Singh, Z., Dhillon, B.S. and Gosal, S.S. (1995) Somatic Embryogenesis and Plant Regeneration in Mandarin (Citrus reticulata Blanco). Scientia Horticulture, 63, 167-174. http://dx.doi.org/10.1016/0304-4238(95)00812-8

[17] Miah, M.N., Islam, S. and Hadinzzaman, S. (2002) Regeneration of Plantlets through Somatic Embryogenesis from Nucellus Tissues of Citrus macroptera Mont. var. anammensis (SatKara). Plant Tissue Culture, 12, 167-172.

[18] Mukhtar, R., Mumtaz, M.K., Ramzan, R., Adnan, S. and Ahmad, K. (2005) In Vitro Regeneration and Somatic Embryogenesis in (Citrus aurantifolia and Citrus sinensis). International Journal of agriculture and Biology, 3, 518-520.

[19] Al-Taha, H.A.K., Abbas, M.J. and Muayed, F.A. (2012) Somatic Embryogenesis and Plantlet Regeneration from Nucleus Tissues of Local Orange (Citrus sinensis (L.) Osbeck). Acta Agriculture Slovenica, 99, 185-189.

[20] Huang, T., Peng, S., Dong, G., Zhang, L. and Li, G. (2002) Plant Regeneration from Leaf-Derived Callus in Citrus grandis: Effects of Auxins in Callus Induction Medium. Plant Cell Tissue and Organ Culture, 69, 141-146. http://dx.doi.org/10.1023/A:1015223701161

[21] Savita, V., Virk, G.S. and Avinash, N. (2010) Effect of Explant Type and Different Plant Growth Regulators on Callus Induction and Plantlet Regeneration in Citrus jambhiri Lush. Environ. International Journal of Science and Technology, 5, 97-106.

[22] Pasqual, M., Cromoko, O.J. and Ando, A. (1984) Somatic Embryogenesis in "Valenci" Orange. Anais do VII Congresso Brasileiro de Fruticultura Florianpolis, 1, 402-407.

[23] Chen, R.Z. and Zhang, L.Y. (1990) A Preliminary Study of the Factors Affecting Embryogenesis and Plantlets Regeneration from Nucellus Tissues of Citrus reticulata cv. Ponkan. Acta-Botanica Aust, 6, 75-80.

[24] Ramdan, R., Handaji, N., Beyahia, H. and Ibriz, M. (2014) Influence of Growth Regulators on Callus Induction from Embryos of Five Citrus Rootstocks. Journal of Applied Biosciences, 73, 5959-5965.

[25] Singh, B., Sharma, S., Rani, G., Virk, G.S., Zaidi, A.A. and Nagpal, A. (2013) In Vitro Flowering in Embryogenic Cultures of Kinnow Mandarin (Citrus nobilis Lour x C. deliciosa Tenora). Global Journal of Agricultural Research, 1, 012-015.

[26] Haoa, Y.J., Wen, X.P. and Deng, X.X. (2004) Genetic and Epigenetic Evaluations of Citrus Calluses Recovered from Slow-Growth Culture. Journal of Plant Physiology, 161, 479-484. http://dx.doi.org/10.1078/0176-1617-01102

[27] Gitarani, G.S.V. and Vinash, N.A. (2003) Callus Induction and Plantlet Regeneration in Sweet Orange (C. sinensis L.) and Lime (C. aurantifolia). In Vitro Cellular and Developmental Biology, 39, 468-474.

[28] Khan, J.A., Jaskani, M.J., Abbas, H. and Khan, M.M. (2006) Effect of Light and Dark Culture Conditions on Callus Induction and Growth in Citrus (Citrus reticulata Blanco). International Journal of Biology and Biotechnology, 3, 669-672.

[29] Gloria, F.J., Filho, M.M., Camargo, A.A. and Mendes, L.E.A. (2000) Plant Regeneration from protoplast of Brazilian citrus cultivars. Époques Agropecuaria Brasileira, Brasilia, 35, 727-732. http://dx.doi.org/10.1590/s0100-204x2000000400008

[30] Verdeil, J.L., Alemanno, L., Niemenak, N. and Tranbarger, T.J. (2007) Pluripotent versus totipotent Plant Stem Cells: Dependence versus Autonomy? Trends in Plant Sciences, 12, 245-252. http://dx.doi.org/10.1016/j.tplants.2007.04.002

[31] Tomaz, M., Mendes, B.J., Filho, A.M. and Rodrigues, P.M. (2001) Somatic Embryogenesis in Citrus Species. In Vitro Cellular and Developmental Biology, 37, 446-452. http://dx.doi.org/10.1007/s11627-001-0078-y

[32] Rajdan, M.K. (1993) An Introduction to Plant Tissue Culture. Oxford and IBH Publisher, New Delhi, India, 94 p.

[33] Jumin, H.B. (2013) Plant Regeneration via Somatic Embryogenesis from Protoplast of Clausena Harmandiana (Engl.) Swing and M. Kell. Analele Universităţii din Oradea, Fascicula Biology, 1, 23-28.

[34] D Onghia, A.M., Carimi, F., De Pasquale, F., Djelouah, K. and Martelli, G.P. (2001) Elimination of Citrus psorosis virus by Somatic Embryogenesis from Stigma and Style Cultures. Plant Pathology, 50, 266-269. http://dx.doi.org/10.1046/j.1365-3059.2001.00550.x

[35] Rana, J.S. and Singh, R. (2002) In Vitro Clonal Propagation of Kagzi Lime (Citrus aurantifolia Swingle) through Shoot tips. Progressive Horticulture, 34, 27. 